\title{
Antibacterial Activity of Sappan Wood (Caesalpinia sappan L.) against Aggregatibacter actino mycetemcomitans and Porphyromonas gingivalis
}

Hendrik Setia Budi ${ }^{1}$, Pratiwi Soesilowati ${ }^{1}$, M itha J ati W irasti $^{2}$

${ }^{1}$ Department of Oral Biology, Faculty of Dental Medicine, Universitas Airlangga, Surabaya - Indonesia

${ }^{2}$ Undergraduate Student, Faculty of Dental Medicine, Universitas Airlangga, Surabaya - Indonesia

*Correspondence: Hendrik Setia Budi, Department of Oral Biology, Faculty of Dental Medicine, Universitas Airlangga. Jln. Mayjend Prof. Dr. Moestopo no. 47 Surabaya 60132, Indonesia.

E-mail: hendrik-s-b@fkg.unair.ac.id

Article History:

ABSTRACT

The aim of this study was to find the Minimum Inhibitory Concentration (MIC) and Minimum Bactericidal Concentration (MBC) of sappan wood ethanol extract (Caesalpinia sappan L.) toward the growth of $A$ actinomycetemcomitans and $P$. gingivalis. The randomized post test only control group design was applied to this study. The sappan wood ethanol extract was conducted with maceration method using 96\% ethanol. Diluted to $50 \%, 25 \%, 12.5 \%, 6.25 \%, 3.125 \%, 1.56 \%, 0.78 \%$ and $0.39 \%$ concentration. The MIC and MBC values of sappan wood ethanol extract toward $A$. actinomycetemcomitans and $P$. gingivalis was then known via the evaluation for Colony Forming Units (CFUs) In $\mathrm{MH}$ medium. The MIC and MBC of sappan wood ethanol extract toward $A$. actinomycetemcomitans and $P$. gingivalis was at $1.56 \%$ and $3.125 \%$ concentration. The ethanol extract of sappan wood reduces the

\section{INTRODUCTION}

Periodontal disease is a chronic inflammatory disease that affects the gum tissue and bone supporting the teeth, which is indicated by gingival inflammation and periodontal pockets (periodontitis) and the second most common dental disease suffered by the world population. Periodontitis is a chronic infectious disease caused by microorganisms. Its key features include periodontal pocket formation, loss of connective tissue attachment, alveolar bone resorption, and gingival inflammation. The studies states that periodontal disease occurs in $20-50 \%$ of the entire population, and can increase the risk of cardiovascular disease by $19 \%$; this risk increases by $44 \%$ at the 65 years old. ${ }^{1,2,3}$ It is not yet known for sure of the complications that can happen in patients with untreated caries or periodontal disease. Those conditions can cause pain, distinction, bad appearance, and disruption of everyday activity. ${ }^{4,5}$

Periodontitis can be treated mechanically, surgically, and with supportive treatment. Chlorhexidine is one of the mouthwashes often recommended for supportive treatment to treat periodontal disease because of its antibacterial and antiplaque effect. Extended usage of chlorhexidine could lead toward changes in tooth color and dorsal part of the tongue, increasing the buildup of calculus, change the taste perception and drying of the oral mucosa. ${ }^{6,7}$ Antibiotic can be used as a supportive treatment because of its ability to decrease the bacterial growth that still exists after mechanical therapy. But, even so, the inaccurate and extended administration of antibiotic could lead to bacterial resistance, this has created the need for a therapy using natural ingredients with antibacterial effects to be developed. . $^{8}$

Sappan (Caesalpinia sappan L.) is a plant from the Febaceae family which grows in tropical region and the stem of the
Revised: 16.03 .2020

Accepted: 19.03 .2020

number of bacterial colonies significantly at $p=0.00$. This study concluded that the growth of $A$. actinomycetemcomitans and $P$. gingivalis can be inhibited by sappan wood ethanol extract (Caesalpinia sappan L.) at MIC $1.56 \%$ and MBC $3.125 \%$ concentration

Keywords: Sappan wood ethanol extract, MIC 1.56\%, MBC $3.125 \%$ Aggregatibacter actinomycetemcomitans, Porphyromonas gingivalis. Correspondence:

Hendrik Setia Budi,

Department of Oral Biology, Faculty of Dental Medicine, Universitas Airlangga. JIn. Mayjend Prof. Dr. Moestopo no. 47 Surabaya 60132 Indonesia.

E-mail: hendrik-s-b@fkg.unair.ac.id

DOI: $10.5530 /$ srp.2020.3.43

@Advanced Scientific Research. All rights reserved plant has been used as traditional medicine since previous times. ${ }^{10}$ Sappan wood contains active compounds in the form of flavonoids, which are homoisoflavonoid, brazilin, protosappanin and chalcone, saponin, terpenoid and tannin. ${ }^{11}$ Brazilin acts as an antibacterial agent to inhibit the synthesis of amino acid and cellular proteins in bacteria. Thus, Brazilin has a high antibacterial efficacy toward $\mathrm{S}$. mutans, a caries-triggering bacteria and $\mathrm{P}$. intermediate, a negative gram bacteria that causes periodontal diseases. ${ }^{12,13}$ In previous study, sappan wood was proven to be able to inhibit bacterial growth such as S. typhi, K. pneumonia, E. coli, B. subtilis, P. aerogenosa and S. aureus. ${ }^{14}$ Sappan wood extract has an antibacterial effect against $E$. faecalis, $S$. salivarius, S. sanguinis and A. viscosus. ${ }^{15}$ The aim of this study was to find the M inimum Inhibitory Concentration (MIC) and M inimum Bactericidal Concentration (M BC) of sappan wood ethanol extract (Caesalpinia sappan L.) toward the growth of $A$. actinomycetemcomitans and $P$. gingivalis which caused periodontal infections.

\section{MATERIALSAND METHODS}

\section{Samples and Ethical clearance}

The bark from sappan wood which has been crushed to a powder was collected by 1650 gram, then macerated twice with $96 \%$ ethanol, then inserted to a digital shaker with the speed of 50rpm for 24 hours and then filtered with a cloth filter to obtain filtrate. The filtrate was then evaporated using Rotary Vacuum Evaporator at the temperature of $40^{\circ} \mathrm{C}$ for 13 hours until a thick extract with $100 \%$ concentration was obtained. ${ }^{16}$ This study was approved by the Health Research Ethical Clearance Committee of the Faculty of Dental Medicine, Universitas Airlangga, Indonesia, 206/HRECC.FODM /2018. 
Preparation of A. actinomycetemcomitans and $P$. gingivalis culture

The colony of $A$. actinomycetemcomitans and $P$. gingivalis bacteria that was taken from the stock using sterile inoculation loop was inserted to the BHIB. After that, the bacterial culture in the BHIB medium was inserted to an anaerobic jar in an anaerobe state and incubated inside an incubator at the temperature of $37^{\circ} \mathrm{C}$ for 24 hours. Then, the culture's turbidity was observed to be equalized with the 0.5 M cFarland standard $\left(1.5 \times 10^{8} \mathrm{CFU} / \mathrm{ml}\right)$.

\section{Determination of antibacterial activity}

Eleven sterile reaction tubes were prepared and labeled with numbers 1-9, $(+)$ for the positive control group and (-) for negative control group. The number 1 sterile tube was filled with $10 \mathrm{ml}$ of $100 \%$ sappan wood ethanol extract, and, in tube numbers 2-9, the positive control tubes and negative control tubes were filled with $5 \mathrm{ml}$ of BHIB medium. Then, $5 \mathrm{ml}$ of solution from tube 1 was added into tube 2 , thus, half the concentration of sappan wood ethanol extract was obtained by mixing $5 \mathrm{ml}$ of BHIB and $5 \mathrm{ml}$ of $100 \%$ sappan wood ethanol extract. After that, $5 \mathrm{ml}$ of mixture was taken from tubenumber 2 and inserted in tubenumber 3 to obtain $25 \%$ concentration of ethanol extract. The procedure was repeated until tube number 9 so that a group of sappan wood ethanol extract with $12.5 \%, 6.25 \%, 3.125 \%, 1.56 \%$, $0.78 \%$, and $0.39 \%$ was obtained. The positive control tubes contained BHIB medium and bacteria, and the negative control tubes only contained BHIB medium; $0.1 \mathrm{ml}$ bacteria was then inserted into tube numbers 1-9 and the positive control tubes. All tubes were incubated at the temperature of $37^{\circ} \mathrm{C}$ for 24 hours to observe the turbidity after the procedure. Results from the dilution technique were then cultivated in the Mueller Hinton medium with streak method to obtain MIC and MBC number. ${ }^{17}$ In order to obtain a more accurate result, $0.1 \mathrm{ml}$ of bacteria from each tube, including positive and negative control, was subcultured with spreader method on a Mueller Hinton medium to count the number of bacterial colonies that had grown. The calculation of growing colony in each concentration was manually counted three times, each with a different observer.

\section{Statistical analysis}

The data of the bacterial colonies was analyzed statistically using SPSS version 17.0 (IBM, Armonk, N ew York, USA). We performed Anova to compare CFU between groups concentration and the post hoc analysis was performed using Tukey H onest Significant Difference Test (HSD).

\section{RESULTSAND DISCUSSION}

According to the qualitative phytochemical analysis of the sappan wood ethanol extract, contents of flavonoid, alkaloid, saponin, and terpenoid active substances were discovered to have antibacterial potential (Table 1).

Table 1: Phytochemical Test Result on Sappan W ood Ethanol Extract

\begin{tabular}{ll}
\hline Active Substance & Phytochemical Test Result \\
\hline Flavonoid & + \\
Tannin & + \\
Terpenoid & + \\
Saponin & + \\
Alkaloid & + \\
\hline
\end{tabular}

N otes: $(+)$ indicates the existence of substances in the extract

Dilution method was carried out in order to find the antibacterial potential of sappan wood ethanol extract, (Caesalpinia sappan), hence, its Minimum Inhibitory Concentration (MIC) and Minimum Bacterial Concentration (MBC). This method was done by adding sappan wood ethanol extract into BHIB, in which after, A. actinomycetem comitans and $P$. gingivalis were inserted to be tested. The result of the dilution method continued with cultivation in each tube with streak method in a Mueller Hinton medium to obtain MIC and M BC (Figure 1). 


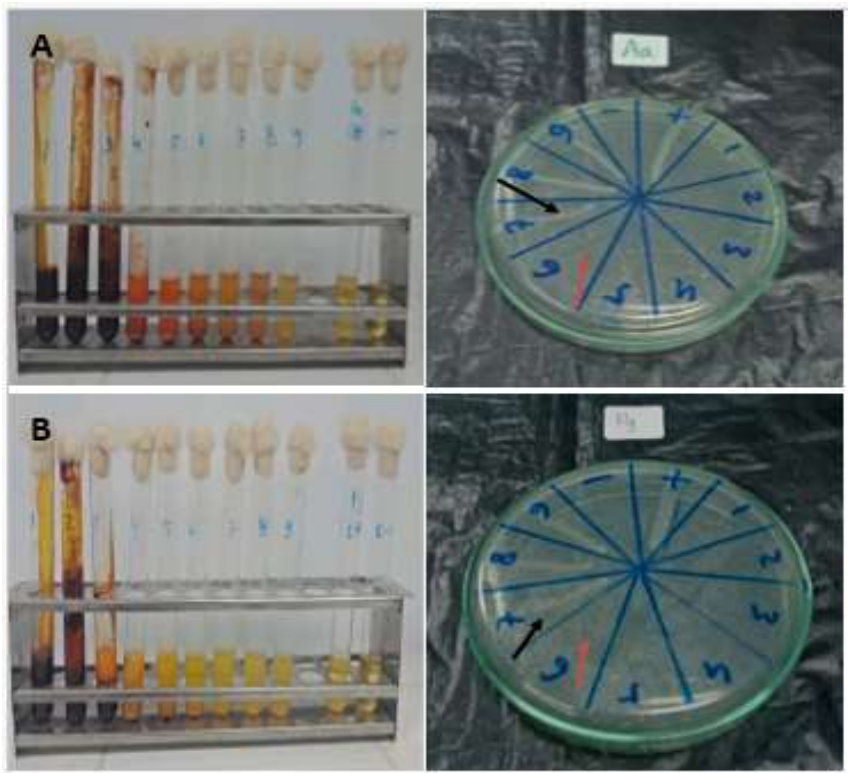

Figure 1: Sappan W ood Ethanol Extract Antibacterial Potential toward A. Actinomycetemcomitans bacteria and P. gingivalis. Annotation: A. Observation of turbidity with dilution method and B. Observation of bacterial colony on the M ueller Hinton using streak method. Tube Number $1-9$ consecutively with $100 \%, 50 \%, 25 \%, 12.5 \%, 6.25 \%, 3.125 \%, 1.56 \%, 0.78 \%$, and $0.39 \%$. Tube with (+) mark was positive control and (-) mark was negative control. The area indicated by red arrow did not show growth of bacterial colony, area indicated by black arrow showed growth of bacterial colonies.

The cultivation of sappan wood ethanol extract in each concentration which had been administered with bacteria A. actinomycetemcomitans and P. gingivalis were conducted in Mueller Hinton medium with three replications. The result showed that, in the positive control, an average of 139 A. actinomycetemcomitans colonies was spotted, meanwhile, in the sappan wood ethanol extract with $100 \%$, $50 \%, 25 \%, 12.5 \%, 6.25 \%$, and $3.125 \%$ concentration and negative control, no bacterial colony growth. In $1.56 \%$ concentration, an average of 12.667 colonies. M eanwhile, in each of the $0.78 \%$ and $0.39 \%$ were 31.67 and 42 colonies. The result from the calculation of $P$. gingivalis colony in positive control averaged at 138,667 colonies, at $100 \%, 50 \%, 25 \%$, $12.5 \%, 6.25 \%$ and $3.125 \%$ concentration and negative control, there was no growth of $\mathrm{P}$. gingivalis colony. The number of colonies on $1.56 \%$ concentration was 11,667 colonies and at $0.78 \%$ and $0.39 \%$ were 32,334 and 49,667 colonies, respectively (Table 2 ).

Table 2: A verage of bacterial colony growth

\begin{tabular}{llll}
\hline $\begin{array}{l}\text { Groups } \\
\text { (Concentration) }\end{array}$ & $\begin{array}{l}\mathrm{n} \\
\text { (repetition) }\end{array}$ & $\begin{array}{l}\text { A. actinomycetemcomitans } \\
\text { (CFU) }\end{array}$ & $\begin{array}{l}\text { P. gingivalis } \\
\text { (CFU) }\end{array}$ \\
\hline $100 \%$ & 3 & - & - \\
$50 \%$ & 3 & - & - \\
$25 \%$ & 3 & - & - \\
$12.5 \%$ & 3 & - & - \\
$6.25 \%$ & 3 & - & - \\
$3.125 \%$ & 3 & - & $11,67^{\mathrm{a}}$ \\
$1.56 \%$ & 3 & $12,67^{\mathrm{a}}$ & $32,33^{\mathrm{b}}$ \\
$0.78 \%$ & 3 & $31,67^{\mathrm{b}}$ & $49,67^{\mathrm{c}}$ \\
$0.39 \%$ & 3 & $42,0^{\mathrm{c}}$ & $138,67^{\mathrm{d}}$ \\
Positive Control & 3 & $139,0^{\mathrm{d}}$ & - \\
Negative Control & 3 & - & - \\
\hline
\end{tabular}

The different superscript letters in a column are significantly different $(p<0.05)$.

\section{DISCUSSION}

A. actinomycetemcomitans and P. gingivalis have a relationship to pathogenesis of the periodontal tissue. The ultrasonic scaling and laser therapy are efforts to decrease the severity of a disease, thus requiring other modes of therapy. ${ }^{18}$ The result of sappan wood study revealed contents of active substances such as flavonoid, saponin, alkaloid, tannin and terpenoid. Flavonoid can disrupt the formation of cell membraneand damage the permeability of bacteria's cell walls and inhibit the function of the cell membrane. 19,20

Other study has also revealed that flavonoid can inhibit expression of inflammatory cytokine by lipopolysaccharide, ${ }^{21}$ which are one of themain components 
from negative gram bacteria virulence, such as $A$. actinomycetemcomitans. ${ }^{22}$ Brazilin was included into the flavonoid group that had the potential as anti-inflammatory, antioxidant and antibacteria. ${ }^{23}$ The tannin mechanism can inhibit DNA synthesis in the A. actinomycetemcomitans bacteria. Tannin can deactivate cellular adhesion of the $P$. gingivalis which, in turn, inhibits the enzyme that triggers protein transport, rendering it disrupted inside the inner membrane of the microbial cell. ${ }^{24}$

The effectivity of saponin as antibacterial agent worked by triggering leakage of protein and enzymes inside the cell and reducing the stability of the cell membrane. The active substance, terpenoid, can disrupt the formation process of cell walls and membranes; this caused the stability of the cell walls to be disrupted and killed the bacteria. ${ }^{25,26,27} \mathrm{High}$ quantities of alkaloids were found in various tissues of $C$. sappan twig. Alkaloids and their derivatives are used for analgesic, antispasmodic and antibacterial effects, anticancer activity and anti-inflammatory activity. ${ }^{28,29}$

The flavonoids, alkaloids, tannins, saponins, and terpenoids are active substances from sappan wood ethanol extract with each of its working mechanisms working in synergy to combat A. actinomycetemcomitans and P. gingivalis bacteria. Those mechanisms caused a decline in the physiological activity of the bacteria, which caused an inhibition toward the bacteria's growth, and, in turn, killed the bacteria. ${ }^{30}$

The result showed that $1.56 \%$ concentration of sappan wood ethanol extract expressed an inhibitory effect toward the growth of A . actiomycetemcomitans bacteria at $90.887 \%$ toward the positive control group. This showed MIC value at the concentration of $1.56 \%$, which according to the study conducted by Khan et al. (2016). ${ }^{31}$ The M IC value of sappan wood ethanol extract toward $P$. gingivalis was obtained at $1.56 \%$ concentration at $91.587 \%$ inhibition rate toward the growth of $P$. gingivalis in positive control group.

Sappan wood ethanol extract was capable of killing A. actinomycetemcomitans at $3.125 \%$, as it was observed that bacterial growth was halted at this concentration. The M BC value of sappan wood ethanol extract toward $P$. gingivalis was also at $3.125 \%$ because, at the appropriate concentration, there was no longer bacterial colony growth observed. The M BC was defined as the lowest concentration needed for an antimicrobial agent to kill $99.9 \%$ of bacteria. Increased concentration of sappan wood extract provides more active antimicrobial substances. Therefore, giving a higher concentration have a potential in inhibiting microbial growth. There were no differences observed in the sensitivity of the bacteria from sappan wood extract between A. actinomycetemcomitans and $P$. gingivalis.

\section{CONCLUSION}

This study concluded that the growth of A. actinomycetemcomitans and $P$. gingivalis can beinhibited by sappan wood ethanol extract (Caesalpinia sappan L.) at M IC $1.56 \%$ and $M B C 3.125 \%$ concentration.

\section{CONFLICT OF INTERESTS}

The authors declare that they have no competing interests.

\section{ACKNOWLED GEMENTS}

The authors would like to acknowledge the contributions of Departement of Oral Biologi staff for supporting the data processing.

\section{REFERENCES}

1. Tsuchida S, Satoh M, Takiwaki M, Nomura F. Ubiquitination in Periodontal Disease: A Review. Int J Mol Sci 2017; 18:1476

2. Petersen PE and Ogawa $\mathrm{H}$. The global burden of periodontal disease: towards integration with chronic disease prevention and control. Period 2000 2012; 60(1):15-39.

3. Chauhan VS, Chauhan RS, Devkar N, Vibhute A, $M$ ore $S$. Gingival and periodontal diseases in children and adolescents. J Dent Allied Sci 2012;4(5):26-9.

4. Manji F. Dahlen $G$ and Fejerskov O. Caries and periodontitis: Contesting the conventional wisdom on their aetiology. Caries Res 2018;52:548-64.

5. Newman M G, Takei H, Klokkevold PR, Carranza FA. Carranza's clinical periodontology 12th Ed. St Louis:Elsevier saunders 2015:47,137,728.

6. Zaugg B, Sahrmann P, Roos M, Attin T, Schmidlin PR. Improving scaling and root planing over the past 40 years: a meta-analysis. Dentistry 2014;4(3):2-5.

7. Najafi M H, Taheri M, M okhtari MR, Forouzanfar A, Farazi F, M irzaee $M$, et al. Comparative study of $0.2 \%$ and $0.12 \%$ digluconate chlorhexidine mouth rinses on the level of dental staining and gingival indices. Dent Res] 2012;9(3):305-8.

8. Tjekyan S. Pola kuman dan resistensi antibiotik di Pediatric Intensive Care Unit (PICU) RS. Dr. Mohammad Hoesin Palembang Tahun 2013 J Ked Kes. 2015;2(2):91-7.

9. Ventola $\mathrm{CL}$. The antibiotic resistance crisis. Pharm Ther 2015;40(4):277-83

10. Senthilkumar N, M urugesan S, Banu N, Supriya S, Rajeshkannan C. Biochemical estimation and antimicrobial activities of the extracts of Caesalpinia sappan Linn. Bangladesh J Sci Ind Res 2011;46(4):42936.

11. Konan $Y$, W itabouna KM, Bassirou B, Kagoyire K. Antioxidant activity and total phenolic content of nine plants from Côte d'I voire (W est Africa). J Appl Pharm Sci 2014;4(8):36-41.

12. Pawar CR, Landge AD and Surana SJ. Phytochemical and pharmacological aspects of Caesalpinia sappan. J Pharm Res 2008;1(2):131-8.

13. Nirmal NP, Rajput MS, Prasad RG, Ahmad M. Brazilin from Caesalpinia sappan heartwood and its pharmacological activities: A review. A sian Pac J Trop M ed 2015;8(6):421-30.

14. Puttipan $R$, W anachantararak $P$, Khongkhunthian $S$, Okonogi S. Effects of Caesalpinia sappan on pathogenic bacteria causing dental caries and gingivitis. Drug Discov Ther 2017;11(6):316-22.

15. Keramat $H, M$ oaddabi $A$ and Ranjbari $A$. In vitro antimicrobial effects of aqueous extracts of 
Caesalpinia sappan Linn derivatives against oral pathogens. Indian J Sci Res 2014;7(1):342-7.

16. Agoes G. Natural material technology. Revised ed. Bandung: ITB Press 2009:37,85.

17. Jorgensen $\mathrm{JH}$ and Ferraro MJ. Antimicrobial susceptibility testing: A review of general principles and contemporary practices. Clin Infect Dis 2009;49:1749-55.

18. Akiyama S, Amano A, Kato T, Takada Y, Kimura KR, M orisaki I. Relationship of periodontal bacteria and Porphyromonas gingivalis fimA variations with phenytoin-induced gingival overgrowth. Oral Dis 2006;12(1):51-6.

19. Kumar $\mathrm{S}$ and Pandey AK. Chemistry and biological activities of flavonoids: an overview. Sci World J 2013;162750.

20. Yury ST, Yuri AK, Elena AY, Eugeny N M . Flavonoidmembrane interactions: Involvement of flavonoid_ metal complexes in raft signaling. Biochimica et Biophysica Acta (BBA) - Biomembranes 2014;1838(5):1235-46.

21. Jiang $F$, Guan $H$, Liu D, Wu X, Fan M, Han J. Flavonoids from sea buckthorn inhibit the lipopolysaccharide-induced inflammatory response in RAW 264.7 macrophages through the MAPK and NF- $\kappa$ B pathways. Food Funct. 2017;8(3):1313-22.

22. Gutiérrez VG, Kawasaki CP, Arroyo CSR, M aldonado FS. Luteolin inhibits lipopolysaccharide actions on human gingival fibroblasts. Eur J Pharmacol. 2006;541(1-2):95-105.

23. Wang $Y$, Sun $S$, and Zhou $Y$. Extract of the dried heartwood of Caesalpinia sappan $L$. attenuates collagen-induced arthritis. J Ethnopharm 2011;136(1):271-8.

24. Nafisyah $A L$, Tjahjaningsih $W$, Kusdarwati $R$, Abdillah AA. Effect of red algae (Kappaphycus alvarezii) on the quality of mackerel (Rastrelliger $\mathrm{sp}$.). J IIm Perik Kel 2015;7(1):87-93.

25. Mujeeb F, Bajpai $P$, and Pathak N. Phytochemical evaluation, antimicrobial activity, and determination of bioactive components from leaves of A egle marmelos. Biomed Res Int 2014;497606.

26. Berti $\mathrm{PL}, \mathrm{N}$ awawi $\mathrm{S}$ and $\mathrm{N}$ ingsih JR. Antibacterial effect of lemon juice (Citrus Limon (L.) Burm. F.) against porphyromonas gingivalis dominant in periodontitis (In Vitro). Dissertation. Universitas M uhammadiyah Surakarta. 2015:3-12.

27. Bello F, Babandi A and M urtala Y. Phytochemicals as Potential Alternatives to Counteract Bacterial Antibiotic Resistance: A M ini-Review. J Biomed Sci 2016;1:124-41.

28. Nilesh PN, M ithun SR, Rangabhatla GSVP, M ehraj A. Brazilin from Caesalpinia sappan heartwood and its pharmacological activities: A review. A sian Pac J Trop M ed. 2015;8(6):421-30.

29. Senthilkumar N, M urugesan S, Bhanu S, Supriya S, Rajeshkannan C. Biochemical estimation and antimicrobial activities of the extracts of Caesalpinia Sappan Linn. Bangladesh J. Sci. Ind. Res. 2011;46(4):429-36.
30. Cushnie $\mathrm{T}$ and Lamb AJ. Recent advances in understanding the antibacterial properties of flavonoids. Int J Antimic Ag 2011;38(2):99-107.

31. Khan R, Islam B, Akram M, Shakil S, Ahmad AA, Ali $S M$, et al. A ntimicrobial activity of five herbal extracts against multi drug resistant (M DR) strains of bacteria and fungus of clinical origin. M ol 2009;14(2):586-97.

32. Barbalho, S.M., Tofano, R.J., Bechara, M.D., Quesada, K., Coqueiro, D.P., M endes, C.G. Castelli index and estimative of $L D L-C$ particle size may still help in the clinical practice? (2016) Journal of Cardiovascular Disease Research, 7 (2), pp. 86-89. DOI: 10.5530/jcdr.2016.2.6 